\title{
Bacterial growth in chicken breast fillet submitted to temperature abuse conditions
}

\author{
Caroline Fátima CASANOVA ${ }^{1}$, Marina Andreia de SOUZA ${ }^{1}$, Bruno FISHER ${ }^{1}$, Rosicler COLET ${ }^{1}$, \\ Cristiane Michele MARCHESI ${ }^{1}$, Jamile ZENI ${ }^{1 *}$ (D), Rogério Luis CANSIAN ${ }^{1}$ Geciane Toniazzo BACKES $^{1}$, \\ Clarice STEFFENS ${ }^{1}$
}

\begin{abstract}
Given possible temperature variations in the cold chain during retail display of chilled food, this work evaluated the growth of Salmonella choleraesuis and Staphylococcus aureus inoculated in chicken breast fillet submitted to different temperature abuses. The bacterial growth was evaluated in Luria-Bertani broth and previously inoculated chicken breast fillet cooled for $12 \mathrm{~h}$ and incubated at different temperatures $\left(5,20\right.$, and $\left.25^{\circ} \mathrm{C}\right)$ for $12 \mathrm{~h}$ and $5{ }^{\circ} \mathrm{C}$ for 12 days. The maximum growth rate and maximum growth were determined. The microorganisms grew at all studied temperatures, with a significantly lower growth at $5{ }^{\circ} \mathrm{C}$ compared with 20 and $25^{\circ} \mathrm{C}$. S. choleraesuis showed higher growth than S. aureus in both culture medium and chicken breast, and major maximum growth in culture medium than chicken breast, at all studied temperatures. Salmonella sp. and S. aureus were not detected in the control treatment maintained at $5{ }^{\circ} \mathrm{C}$, and the thermotolerant bacteria remained within the standards allowed by Brazilian legislation when stored for 12 days. However, temperature abuse resulted in the vulnerability and spoilage of chicken breast fillet quality. The effects of temperature abuse caused by negligence on the microbial growth $\left(\mathrm{Y}_{\max }\right)$ and growth rate $\left(\mu_{\max }\right)$ in chicken breast fillet, under industrial conditions was demonstrated.
\end{abstract}

Keywords: Staphylococcus aureus; Salmonella choleraesuis; thermotolerant bacteria; food safety; cold chain.

Practical Application: The kinetic and growth parameters of pathogenic microorganisms at abuse temperature was determinate.

\section{Introduction}

Efficient management of the food supply chain requires maintaining optimal product storage conditions from point of origin to point of consumption. According to good manufacturing practices, temperature is the main determinant of post-expiration dates, being the most important factor affecting food quality and safety (Taoukis, 2008; Taoukis et al., 2016).

Perishable products, such as fresh meat and especially cold chain products, may suffer temperature fluctuations and/or abuse, exceeding the safe storage limit of $5{ }^{\circ} \mathrm{C}$ (Laguerre et al., 2002; Nychas et al., 2008). These unexpected changes or cold chain temperatures may compromise food safety and quality due to the rapid growth of pathogenic bacteria such as Salmonella choleraesuis and Staphylococcus aureus, resulting in loss of consumer confidence and increased levels of food waste and economic losses (Franciosi et al., 2011; Gustavsson et al., 2011; Yehia et al., 2020).

Several studies have shown that temperature abuses occur at all stages of the cold chain and are related to many food products. Some products evaluated include fresh produce and its juice extracts (Huang et al., 2019), fruits and vegetables (Goedhals-Gerber et al., 2017), fresh meat, meat and vegetable preparations (Zubeldia et al., 2016), bagged salad (Brown et al., 2016), sliced ham (Derens-Bertheau et al., 2015), minced meat and processed fish (Lundén et al., 2014a) and ready-to-eat foods (Lundén et al., 2014b).
The cold chain is related to the quality of the final product by two different but complementary aspects: (i) microbiological contamination and the risk associated with human health; (ii) the organoleptic and sensory characteristics of the final product (Man, 2016; Mataragas et al., 2019). Therefore, microbial control and monitoring of the cold chain from production to final consumer is essential for the production of safe food with guaranteed shelf life (Kreyenschmidt et al., 2010). The temperature of household refrigerators and retail stores is considered a critical point in the supply chain (Limbo et al., 2010). The products displayed from supermarkets are handled by consumers and transported to their homes at a constant $\left(25^{\circ} \mathrm{C}\right)$ high ambient temperature before returning to the freezer, so that microbial growth can occur (Karthikeyan et al., 2015).

In industries, temperature monitoring is usually performed by random measurements of the product core. In distribution, this aspect is mainly controlled by data loggers, which measure the ambient temperature. Due to their advantages, these monitoring systems are applied from production to retail (Koutsoumanis, 2001; Kreyenschmidt et al., 2010). However, cold chain interruptions can occur at the point of sale, on the retailer's path to the consumer and during home storage, and are not yet integrated into this monitoring concept (Limbo et al., 2010).

Poultry products have significant economic importance not only in Brazil but also around the word (Schuch et al., 
2019; Schmidt et al., 2020; Auriema et al., 2019). But, only a few works of literature emphasize the growth of microorganisms in the chicken breast fillet with respect to the speed of growth in different temperature abuses caused by the negligence of some establishments due to the lack of temperature control of refrigerated exhibitors. foods. In this context, the present work evaluated the growth parameters (rate and maximum growth) of Salmonella choleraesuis and Staphylococcus aureus inoculated in chicken breast fillet and subjected to different temperature abuses $\left(5,20\right.$ and $\left.25^{\circ} \mathrm{C}\right)$ for $12 \mathrm{~h}$.

\section{Materials and methods}

The chicken breast fillets were donated by a local agribusiness. This raw material was collected on the day of slaughter and cooled to $4{ }^{\circ} \mathrm{C}$ (Brastemp, Sao Paulo, Brazil) until the time of analysis. A correlation analysis between the microbiological growth in Luria-Bertani (LB) broth and chicken breast fillet subjected to temperature abuse was explored using $S$. choleraesuis (ATCC 10708) and S. aureus (ATCC 6538). The bacterial stock cultures were previously grown in LB broth $(10 \mathrm{~g} / \mathrm{L}$ tryptone; $5 \mathrm{~g} / \mathrm{L}$ yeast extract; $5 \mathrm{~g} / \mathrm{L} \mathrm{NaCl}$; Merck, USA). For bacterial growth, $0.1 \mu \mathrm{L}$ of the stock cultures were transferred to LB broth and incubated at $37^{\circ} \mathrm{C}$ for $24 \mathrm{~h}$. Afterward, the inoculum was prepared by diluting the cell concentration in $0.1 \%$ peptone water to $10^{2} \mathrm{CFU} / \mathrm{mL}$, and $1 \mathrm{~mL}$ of this dilution was transferred to test tubes containing $9 \mathrm{~mL}$ of LB broth. The cell count was enumerated by plating on plate count agar (PCA) medium ( $5 \mathrm{~g} / \mathrm{L}$ tryptone; $2.5 \mathrm{~g} / \mathrm{L}$ yeast extract; $1 \mathrm{~g} / \mathrm{L}$ dextrose; $15 \mathrm{~g} / \mathrm{L}$ agar).

To simulate negligence of the refrigeration in the store, the inoculum was maintained under refrigeration $\left(5^{\circ} \mathrm{C}\right)$ for $12 \mathrm{~h}$ to acclimatize to the cold before the refrigerator was switched off and the door opened to the environment $\left(15^{\circ} \mathrm{C}\right)$. After $2 \mathrm{~h}$ (lag phase), each inoculum was subjected to temperatures of 20 and $25^{\circ} \mathrm{C}$ in an incubator for $10 \mathrm{~h}$. In addition, after the abuse, a sample was conditioned again to refrigeration at $5{ }^{\circ} \mathrm{C}$ for $10 \mathrm{~h}$. The growth kinetics in each condition were determined by plating and counting of the samples withdrawn from the inoculum each hour for $12 \mathrm{~h}$, in triplicate.

Salmonella choleraesuis and S. aureus were inoculated separately into breast fillet pieces $\left(8 \mathrm{~cm}^{3}\right.$ cubes) by immersion of the cubes in $10^{2} \mathrm{CFU} / \mathrm{mL}$ bacterial solution containing $0.1 \%$ peptone water, at room temperature $\left(25^{\circ} \mathrm{C}\right)$ for $10 \mathrm{~min}$. The cubes were then removed from the broth, drained for $1 \mathrm{~min}$. and incubated in polyvinyl chloride packages, hermetically sealed, and kept under refrigeration. Once reaching a stable temperature of $5{ }^{\circ} \mathrm{C}$, the samples were conditioned in an incubator (Nova Ética, São Paulo, Brazil) at 5, 20, and $25^{\circ} \mathrm{C}$ for $10 \mathrm{~h}$. For the microbial count, a sample (around $10 \mathrm{~g}$ of chicken breast) was taken every hour and diluted in $90 \mathrm{~mL}$ of $0.1 \%$ peptone water, followed by plating on PCA medium, in the same manner as for the broth. This procedure was carried out in triplicate for each temperature and time evaluated.

The maximum growth rate $\left(\mu_{\max }\right)$ was determined according to the log of the growth variation $(d X)$ as a function of time $(d t)$, in the exponential phase (Equation 1): $\mu_{\max }=\frac{d X}{d t}$

The maximum growth $\left(Y_{\max }\right)$ was considered as the log of growth after incubation at different temperatures $(5,20$, and $25^{\circ} \mathrm{C}$ ) for $12 \mathrm{~h}$.

A control experiment (blank) was performed, in which samples of breast fillet without immersion in the bacterial inoculum were incubated at $5^{\circ} \mathrm{C}$ for 12 days, with daily determinations of the counts of $S$. aureus, thermotolerant bacteria, and detection of Salmonella sp., in triplicate, based on a previous method (Silva et al., 2017).

The growth kinetic graphs with first order equations were constructed using LibreOffice software.

\section{Results and discussion}

Temperature variations can reduce the shelf life of perishable products, leading to a discrepancy between the final consumption date described on the food label and the legitimate conditions of food quality. The microbiological enumeration results of $S$. choleraesuis and $S$. aureus of the chicken breast fillets samples incubated at 5, 20, and $25^{\circ} \mathrm{C}$ are shown in Figures 1 and 2.

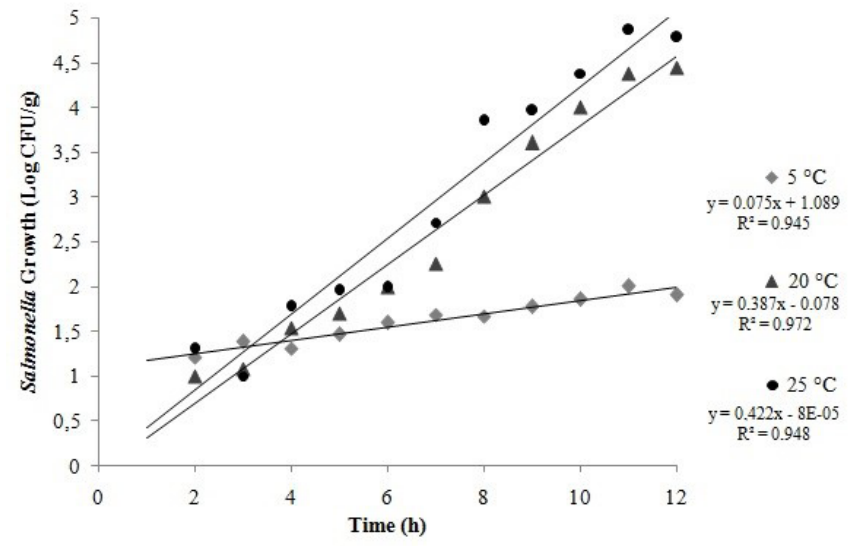

Figure 1. Growth kinetics of Salmonella choleraesuis at 5, 20, and 25 ${ }^{\circ} \mathrm{C}$ in chicken breast fillets.



Figure 2. Growth kinetics of Staphylococcus aureus at 5, 20, and $25^{\circ} \mathrm{C}$ in chicken breast fillets. 
The temperature influenced the growth of Salmonella choleraesuis. The growth was constant until $2 \mathrm{~h}$ of incubation, characterizing the adaptation phase (lag phase) in the medium and the temperature conditions. Exposure to $25^{\circ} \mathrm{C}$ resulted in an increase of approximately $4.78 \log \mathrm{CFU} / \mathrm{mL}$ in $12 \mathrm{~h}$, and a similar growth $(4.44 \log \mathrm{CFU} / \mathrm{mL})$ was observed at $20^{\circ} \mathrm{C}(12 \mathrm{~h})$. Conversely, the samples exposed to $5{ }^{\circ} \mathrm{C}$ exhibited a count of $1.90 \log \mathrm{CFU} / \mathrm{mL}(12 \mathrm{~h})$.

Staphylococcus aureus exhibited a similar growth trend to $S$. choleraesuis under the different temperature conditions (Figure 2), so that it was almost constant until $2 \mathrm{~h}$ of incubation, characterizing the adaptation phase (lag). Temperature abuses of 20 and $25^{\circ} \mathrm{C}$ resulted in a count of 4.43 and $4.66 \log \mathrm{CFU} / \mathrm{mL}$, respectively, at $12 \mathrm{~h}$, which were much higher than $1.84 \log \mathrm{CFU}$ detected in the samples stored at $5{ }^{\circ} \mathrm{C}$.

The heating that is caused by long periods of equipment shutdown, such as at night or on weekends, is a serious problem, providing favorable conditions for the development and reproduction of (often pathogenic) microorganisms, mainly on hot days, with high ambient temperature. This problem results in reduced shelf life, notably of perishable products. For this reason, cold chain management in food supply chains is receiving increasing attention from regulators, industry, and consumers (Ndraha et al., 2018).

According to the Resolution of the Collegiate Board of Directors (RDC) of the National Health Surveillance Agency (ANVISA) no. 216, of September 15, 2004 (Brasil, 2004), the equipment necessary for the consumer presentation or distribution must be appropriately sized, and the temperature monitored regularly. Semi-prepared and fully prepared foods must be cooled from $60{ }^{\circ} \mathrm{C}$ to $10^{\circ} \mathrm{C}$ within $4 \mathrm{~h}$ or less, and stored under refrigeration at temperatures below $5{ }^{\circ} \mathrm{C}$, or frozen at $-18^{\circ} \mathrm{C}$. From that perspective, this study demonstrates the necessity of adequate low-temperature maintenance and control, as the temperature-abused product (above $20^{\circ} \mathrm{C}$ ) had a high microbiological count, representing a high safety risk to customers. According to Pereira et al. (2010), any failure in the cold chain (storage, preservation, distribution, transport, and handling of the products) can compromise the products' quality since the speeds of chemical, biochemical, and microbiological reactions are directly related to the temperature. In addition, the duration of the exposure to anomalous temperatures is equally decisive for refrigerated or frozen foodstuffs safety.

Staphylococcus are microorganisms commonly found among the microflora of raw poultry meat (Russell, 2008). Based on earlier research (Franco \& Landgraf, 2008) between $10^{5}$ and $10^{6} \mathrm{CFU}$ of $S$. aureus per gram of food is necessary to form toxins at levels capable of causing intoxication. Considering this range in the context of the present study, the samples kept at 20 and $25^{\circ} \mathrm{C}$ for $12 \mathrm{~h}$ already pose a risk to consumer health, if the strain was enterotoxigenic.

For S. choleraesuis and S. aureus in LB broth and previously inoculated in chicken breast, submitted to different temperatures $\left(5,20\right.$, and $\left.25^{\circ} \mathrm{C}\right)$ after refrigeration $\left(5^{\circ} \mathrm{C}\right)$ for $12 \mathrm{~h}$ (Table 1$)$, the temperature increase resulted in an increase in the $\mu_{\max }$, with high rates for LB broth growth compared to those inoculated in

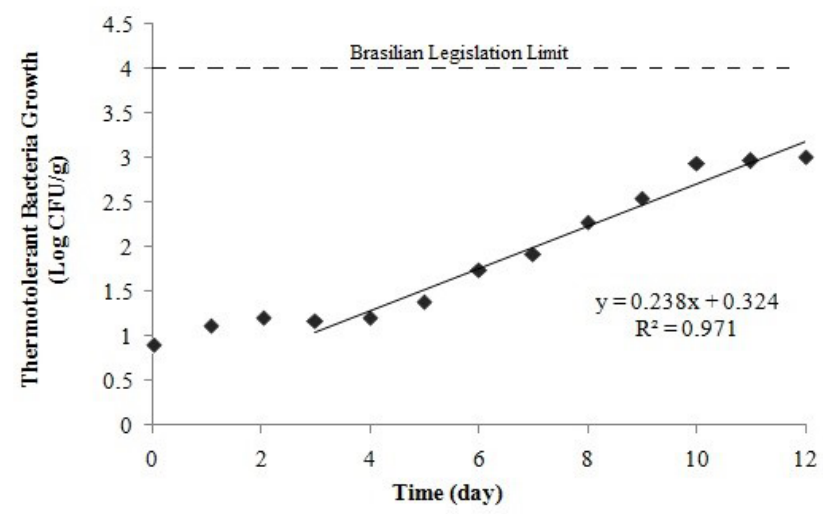

Figure 3. Growth kinetics of thermotolerant bacteria at $5^{\circ} \mathrm{C}$ in chicken breast fillet.

Table 1. Maximum growth rate $\left(\mu_{\max }\right)$ and maximum growth $\left(\mathrm{Y}_{\max }\right)$ of $S$. choleraesuis and $S$. aureus in LB medium and previously inoculated in chicken breast and subjected to temperature abuse.

\begin{tabular}{|c|c|c|c|c|c|}
\hline & \multirow{2}{*}{ Treatments } & \multirow{2}{*}{ Growth parameters } & \multicolumn{3}{|c|}{ Temperatures $\left({ }^{\circ} \mathrm{C}\right)$} \\
\hline & & & 5 & 20 & 25 \\
\hline \multirow{5}{*}{ 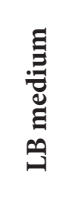 } & S. choleraesuis & $\mu \max (1 / \mathrm{h})$ & 0.08 & 0.42 & 0.48 \\
\hline & & Ymax $(\log \mathrm{CFU} / \mathrm{mL})$ & 1.90 & 5.40 & 6.01 \\
\hline & S. aureus & $\mu \max (1 / h)$ & 0.09 & 0.41 & 0.45 \\
\hline & & Ymax $(\log \mathrm{CFU} / \mathrm{mL})$ & 2.01 & 5.19 & 5.69 \\
\hline & S. choleraesuis & $\mu \max (1 / h)$ & 0.07 & 0.34 & 0.38 \\
\hline \multirow{3}{*}{ 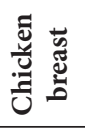 } & & Ymax $(\log \mathrm{CFU} / \mathrm{mL})$ & 1.90 & 4.45 & 4.71 \\
\hline & S. aureus & $\mu \max (1 / \mathrm{h})$ & 0.09 & 0.31 & 0.34 \\
\hline & & Ymax $(\log \mathrm{CFU} / \mathrm{mL})$ & 1.84 & 4.44 & 4.67 \\
\hline
\end{tabular}
population.

chicken breast. Salmonella choleraesuis displayed a growth rate superior to $S$. aureus in both culture medium and chicken breast at 20 and $25^{\circ} \mathrm{C}$. At $5{ }^{\circ} \mathrm{C}$, a low growth rate of $S$. choleraesuis was observed in both growing conditions. The $Y_{\max }$ showed a similar behavior (Table 1), with high growth of $S$. choleraesuis in LB medium for all the temperatures evaluated. However, when inoculated in chicken breast samples, both bacteria had similar $Y_{\max }$.

Salmonella and Staphylococcus bacteria are heat tolerant but are susceptible to destruction when exposed to $55^{\circ} \mathrm{C}$ for $1 \mathrm{~h}$, or $60^{\circ} \mathrm{C}$ for 15 to $20 \mathrm{~min}$ (Gama, 2001; Stewart, 2003). As mentioned by Franco \& Landgraf (2008), bacterial growth is hampered by low temperatures. In the present work, microbial growth (albeit slow) was observed at low temperature $\left(5^{\circ} \mathrm{C}\right)$ after an initial temperature abuse of $15^{\circ} \mathrm{C}$ for $2 \mathrm{~h}$ (Figures 1 and 2).

A control experiment performed with breast fillet without immersion in the bacterial inoculum did not detect counts of $S$. aureus and Salmonella sp. were absent. In analyzing the growth kinetics of the thermotolerant bacteria (Figure 3), delayed growth of both bacteria occurred in the control chicken breast fillets, incubated at $5{ }^{\circ} \mathrm{C}$. 
The chicken breast sample showed a shelf life of 12 days under ideal storage conditions, with a controlled temperature of $5{ }^{\circ} \mathrm{C}$, consistent with the values established by the current Brazilian legislation, of 0 to $4 \pm 1{ }^{\circ} \mathrm{C}$ for refrigerated products (Brasil, 1998; US Food and Drug Administration, 2017). However, the chicken breast samples that suffered temperature abuses (20 and $25^{\circ} \mathrm{C}$ ) should be consumed in the first $12 \mathrm{~h}$. After this time, they would represent a risk to the consumers' health since the limit for a "safe contamination" is $10^{4} \mathrm{CFU} / \mathrm{mL}$ for thermotolerant bacteria (Brasil, 2001). In this light, it is essential to develop strategies for effective temperature control during the supply chain of fresh poultry products or development instruments that allow knowing the temperature values to which the food was exposed and predict its true useful shelf life.

Temperature is one of the most important factors affecting cellular metabolic reactions (Francis et al., 2012; Kou et al., 2014). It is also a critical factor in the survival and growth of pathogens in various food matrices (Huang et al., 2015; Luo et al., 2009; Luo et al., 2010; Sudarshana et al., 2008). Therefore, the proper maintenance of refrigeration during the transportation and storage of meat products is an extremely important practice for product quality and safety.

It should be noted that the low prevalence of all bacteria analyzed at time zero indicated a good process control during the processing stages, with good manufacturing practices by the slaughterhouse. According to the Brazilian Poultry Union (União Brasileira de Avicultura, 2015), the industrial sector has a great interest in the use of non-destructive and reliable techniques to validate thermal processes. A simple and inexpensive technological alternative to ensure the dynamic validity of perishable foods is the use of intelligent packaging containing a colorimetric indicator that can encourage the food producers to deliver products with safety guaranteed (Mehauden et al., 2007) since there is a constant pressure of the consumers and supervising systems for food safety.

\section{Conclusion}

Temperature is a determinant factor in food preservation, as observed in the microbiological results for $S$. choleraesuis and S. aureus, wherein chicken breast demonstrated high bacterial growth when exposed to temperature abuse $\left(20\right.$ and $\left.25^{\circ} \mathrm{C}\right)$. Salmonella choleraesuis presented a high growth rate in LB broth and chicken breast fillet at 20 and $25^{\circ} \mathrm{C}$, and a low growth at $5^{\circ} \mathrm{C}$ when compared with S. aureus. Salmonella choleraesuis also showed a high $Y_{\max }$ in LB broth at all temperatures studied, and a similar $Y_{\max }$ to $S$. aureus when inoculated in chicken breast. For the control sample preserved at favorable temperature conditions $\left(5{ }^{\circ} \mathrm{C}\right)$, without temperature abuse during storage, the microbiological growth was stable during 12 days of analysis. Thus, this work demonstrates the importance of temperature control in chilled chicken breast fillet for the maintenance of quality and safety and can be extended to other meat products.

\section{Acknowledgements}

This study was financed in part by the National Council for Scientific and Technological Development - Brazil (CNPq), Coordination for the Improvement of Higher Education Personnel
- Brazil (CAPES) - Finance Code 001 and Research Support Foundation of the State of Rio Grande of Sul - Brazil (FAPERGS).

\section{References}

Auriema, B. E., Dinalli, V. P., Kato, T., Yamaguchi, M. M., Marchi, D. F., \& Soares, A. L. (2019). Physical and chemical properties of chicken mortadella formulated with Moringa oleifera Lam. seed flour. Food Science and Technology, 39(Suppl. 2), 504-509. http:// dx.doi.org/10.1590/fst.25018.

Brasil. Ministério da Agricultura e do Abastecimento. (1998, November 10). Portaria $\mathrm{n}^{\circ} 210$ de 10 de Novembro de 1998. Regulamento técnico da inspeção tecnológica e higiênico-sanitária de carne de aves. Diário Oficial da União, seção 1.

Brasil. (2001, January 2). Resolução de Diretoria Colegiada - RDC n ${ }^{\circ}$ 12, de 02 de Janeiro de 2001. Diário Oficial da União. Retrieved from http://portal.anvisa.gov.br/wps/wcm/connect/a47bab8047

Brasil. (2004, September 16). Resolução Nº 216, de 15 de Setembro de 2004. Dispõe sobre Regulamento Técnico de Boas Práticas para Serviços de Alimentação. Diário Oficial da União. Retrieved from http://portal.anvisa.gov.br/wps/wcm/connect/4a3b680040bf8cdd8 e5dbf1b0133649b/RESOLU\%C3\%87\%C3\%83O-RDC+N+216+DE $+15+\mathrm{DE}+$ SETEMBRO+DE+2004.pdf?MOD=AJPERES

Brown, W., Ryser, E., Gorman, L., Steinmaus, S., \& Vorst, K. (2016). Temperatures ex-perienced by fresh-cut leafy greens during retail storage and display. Acta Horticulturae, (1141), 103-108. http:// dx.doi.org/10.17660/ActaHortic.2016.1141.10.

Derens-Bertheau, E., Osswald, V., Laguerre, O., \& Alvarez, G. (2015). Cold chain of chilled food in France. International Journal of Refrigeration, 52, 161-167. http://dx.doi.org/10.1016/j.ijrefrig.2014.06.012.

Franciosi, E., Settanni, L., Cologna, N., Cavazza, A., \& Poznanski, E. (2011). Microbial analysis of raw cows' milk used for cheese making: influence of storage treatments on microbial composition and other technological traits. World Journal of Microbiology \& Biotechnology, 27(1), 171-180. http://dx.doi.org/10.1007/s11274-010-0443-2.

Francis, G. A., Gallone, A., Nychas, G. J., Sofos, J. N., Colelli, G., Amodio, M. L., \& Spano, G. (2012). Factors affecting quality and safety of fresh-cut produce. Critical Reviews in Food Science and Nutrition, 52(7), 595-610. http://dx.doi.org/10.1080/10408398.2010.503685 . PMid:22530712.

Franco, B. D. G. M., \& Landgraf, M. Microbiology of food. São Paulo: Editora Atheneu, 2008.

Gama, N. M. S. Q. (2001). Salmonella spp in commercial poultry (MSc thesis). São Paulo: Universidade Estadual Paulista (UNESP).

Goedhals-Gerber, L. L., Stander, C., \& Van Dyk, F. E. (2017). Maintaining cold chain integrity: temperature breaks within fruit reefer containers in the Cape Town Container Terminal. Southern African Business Review, 21, 362-384.

Gustavsson, J., Cederber, C., Sonesson, U., Van Otterdijk, R., \& Meybeck, A. (2011). Global food losses and food waste: extent, causes and prevention. Rome: FAO.

Huang, J., Luo, Y., \& Nou, X. (2015). Growth of Salmonella enterica and Listeria monocytogenes on fresh-cut cantaloupe under different temperature abuse scenarios. Journal of Food Protection, 78(6), 1125-1131. http://dx.doi.org/10.4315/0362-028X.JFP-14-468. PMid:26038902.

Huang, J., Luo, Y., Zhou, B., Zheng, J., \& Nou, X. (2019). Growth and survival of Salmonella enterica and Listeria monocytogenes on fresh-cut produce and their juice extracts: impacts and interactions of food matrices and temperature abuse conditions. Food Control, 100, 300-304. http://dx.doi.org/10.1016/j.foodcont.2018.12.035. 
Karthikeyan, J. S., Desai, K. M., Salvi, D., Bruins, R., Schaffner, D. W., \& Karwe, M. V. (2015). Effect of temperature abuse on frozen army rations: part 2: predicting microbial spoilage. Food Research International, 76(Pt 3), 587-594. http://dx.doi.org/10.1016/j. foodres.2015.07.012. PMid:28455041.

Kou, L., Luo, Y., Park, E., Turner, E. R., Barczakc, A., \& Jurick, W. J. 2nd (2014). Temperature abuse timing affects the quality deterioration of commercially packaged ready-to-eat baby spinach. Postharvest Biology and Technology, 91, 96-103. http://dx.doi.org/10.1016/j. postharvbio.2013.12.025.

Koutsoumanis, K. (2001). Predictive modeling of the shelf life of fish under nonisothermal conditions. Applied and Environmental Microbiology, 67(4), 1821-1829. http://dx.doi.org/10.1128/ AEM.67.4.1821-1829.2001. PMid:11282639.

Kreyenschmidt, J., Christiansen, H., Hübner, A., Raab, V., \& Petersen, B. (2010). A novel photochromic time-temperature indicator to support cold chain management. International Journal of Food Science \& Technology, 45(2), 208-215. http://dx.doi.org/10.1111/j.13652621.2009.02123.x.

Laguerre, O., Derens, E., \& Palagos, B. (2002). Study of domestic refrigerator temperature and analysis of factors affecting temperature: a French survey. International Journal of Refrigeration, 25(5), 653659. http://dx.doi.org/10.1016/S0140-7007(01)00047-0.

Limbo, S., Torri, L., Sinelli, N., Franzetti, L., \& Casiraghi, E. (2010). Evaluation and predictive modeling of shelf life of minced beef stored in high-oxygen modified atmosphere packaging at different temperatures. Meat Science, 84(1), 129-136. http://dx.doi.org/10.1016/j. meatsci.2009.08.035. PMid:20374764.

Lundén, J., Vanhanen, V., Kotilainen, K., \& Hemminki, K. (2014a). Retail food stores' internet-based own-check databank records and health officers' on-site inspection results for cleanliness and food holding temperatures reveal inconsistencies. Food Control, 35(1), 79-84. http://dx.doi.org/10.1016/j.foodcont.2013.06.050.

Lundén, J., Vanhanen, V., Myllymäki, T., Laamanen, E., Kotilainen, K., \& Hemminki, K. (2014b). Temperature control efficacy of retail refrigeration equipment. Food Control, 45, 109-114. http://dx.doi. org/10.1016/j.foodcont.2014.04.041.

Luo, Y., He, Q., \& McEvoy, J. L. (2010). Effect of storage temperature and duration on the behavior of Escherichia coli O157:H7 on packaged fresh-cut salad containing Romaine and Iceberg lettuce. Journal of Food Science, 75(7), M390-M397. http://dx.doi.org/10.1111/j.17503841.2010.01722.x. PMid:21535546.

Luo, Y., He, Q., McEvoy, J. L., \& Conway, W. S. (2009). Fate of Escherichia coli $\mathrm{O} 157: \mathrm{H7}$ in the presence of indigenous microorganisms on commercially packaged baby spinach as impacted by storage temperature and time. Journal of Food Protection, 72(10), 2038-2045. http://dx.doi.org/10.4315/0362-028X-72.10.2038. PMid:19833025.

Man, C. M. D. (2016). Development of a predictive model for spoilage of cooked cured meat products and its validation under constant and dynamic temperature storage conditions. Journal of Food Science, 71, 157-167.

Mataragas, M., Bikouli, V. C., Korre, M., Sterioti, A., \& Skandamis, P. N. (2019). Development of a microbial Time Temperature Indicator for monitoring the shelf life of meat. Innovative Food Science \& Emerging Technologies, 52, 89-99. http://dx.doi.org/10.1016/j.ifset.2018.11.003.

Mehauden, K., Cox, P. W., Bakalis, S., Simmons, M. J. H., Tucker, G. S., \& Fryer, P. J. (2007). A novel method to evaluate the applicability of time temperature integrators to different temperature profiles. Innovative Food Science \& Emerging Technologies, 8(4), 507-514. http://dx.doi.org/10.1016/j.ifset.2007.03.001.

Ndraha, N., Hsiao, H., Vlajic, J., Yang, M., \& Lin, H. V. (2018). Time-temperature abuse in the food cold chain: review of issues, challenges, and recommendations. Food Control, 89, 12-21. http:// dx.doi.org/10.1016/j.foodcont.2018.01.027.

Nychas, G. F., Skandamis, P. N., Tassou, C. C., \& Koutsoumanis, K. P. (2008). Meat spoilage during distribution. Meat Science, 78(1-2), 7789. http://dx.doi.org/10.1016/j.meatsci.2007.06.020. PMid:22062098.

Pereira, V. F., Doria, E. C. B., Carvalho, B. C. Jr, Neves, L. C. Fo, \& Silveira, V. Jr. (2010). Evaluation of temperatures in a refrigerated container for chilled and frozen food transport. Food Science and Technology, 30(1), 158-165. http://dx.doi.org/10.1590/S0101-20612010000100024.

Russell, S. M. (2008). The effect of an acidic, copper sulfate-based commercial sanitizer on indicator, pathogenic, and spoilage bacteria associated with broiler chicken carcasses when applied at various intervention points during poultry processing. Poultry Science, 87(7), 1435-1440. http://dx.doi.org/10.3382/ps.2007-00339. PMid:18577627.

Schmidt, M. M., Fontoura, A. M., Vidal, A. R., Dornelles, R. C. P., Kubota, E. H., Mello, R. O., Cansian, R. L., Demiate, I. M., \& Oliveira, C. S. (2020). Characterization of hydrolysates of collagen from mechanically separated chicken meat residue. Food Science and Technology, 40(Suppl. 1), 355-362. http://dx.doi.org/10.1590/ fst. 14819 .

Schuch, A. F., Silva, A. C., Kalschne, D. L., Silva-Buzanello, A. P., Corso, M. P., \& Canan, C. (2019). Chicken nuggets packaging attributes impact on consumer purchase intention. Food Science and Technology, 39(Suppl. 1), 152-158. http://dx.doi.org/10.1590/fst.41317.

Silva, N., Junqueira, V. C. A., Silveira, N. F. A., Taniwaki, M. H., Gomes, R. A. R., \& Okazaki, M. M. (2017). Manual of methods of microbiological analysis of food and water (5th ed). São Paulo: Bulcher.

Stewart, C. M. (2003). Staphylococcus aureus and staphylococcal enterotoxins. In A. D. Hocking (Ed.), Foodborne microorganisms of public health significance (6th ed, pp. 359-380). Waterloo: Australian Institute of Food Science and Technology (NSW Branch).

Sudarshana, M. R., Bandyopadhyay, S., Rosa, C., Suslow, T., \& Harris, L. J. (2008). Effects of static and variable storage temperatures on the survival and growth of Escherichia coli O157: $\mathrm{H} 7$ on prewashed bagged lettuce. Phytopathology, 98, S152.

Taoukis, P. S. (2008). Application of time-temperature integrators for monitoring and management of perishable product quality in the cold chain. In: P. B. Joseph Kerry (Ed.), Smart packaging technologies for fast moving consumer goods (pp. 61-74). Chichester: John Wiley \& Sons. http://dx.doi.org/10.1002/9780470753699.ch4.

Taoukis, P. S., Gogou, E., Tsironi, T., Giannoglou, M., Dermesonlouoglou, E., \& Katsaros, G. (2016). Food cold chain management and optimization. In: V. Nedović, P. Raspor, J. Lević, V. Tumbas Šaponjac, G. Barbosa-Cánovas (Eds.), Emerging and traditional technologies for safe, healthy and quality food (pp. 285-309). Switzerland: Springer International Publishing.. http://dx.doi.org/10.1007/978-3-31924040-4_16.

União Brasileira de Avicultura - Ubabef. (2015). Annual report. Retrieved from: https://docplayer.com.br/11162507-Relatorio-anual-ubabefuniao-brasileira-de-avicultura.html

US Food and Drug Administration - FDA. (2017) Food Code. College Park: FDA. Retrieved from: https://www.fda.gov/downloads/Food/ GuidanceRegulation/RetailFoodProtection/FoodCode/UCM595140.pdf

Yehia, H. M., Al-Masoud, A. H., Alsawmahi, O. N., Aljahani, A. H., \& El-Din, M. F. S. (2020). Effects of citrox treatment on the survival of Methicillin-Resistant Staphylococcus aureus (MRSA) in chicken fillets packed under vacuum. Food Science and Technology, 40(3), 588-595. http://dx.doi.org/10.1590/fst.13819.

Zubeldia, B. B., Jiménez, M. N., Claros, M. T. V., Andrés, J. L. M., \& Martin-Olmedo, P. (2016). Effectiveness of the cold chain control procedure in the retail sector in Southern Spain. Food Control, 59, 614-618. http://dx.doi.org/10.1016/j.foodcont.2015.06.046. 